\title{
CD28 costimulation independence of target organ versus circulating memory antigen-specific $\mathrm{CD4}^{+} \mathrm{T}$ cells
}

\author{
Andrew P. Fontenot, ${ }^{1,2}$ Laia Gharavi, ${ }^{1}$ Sean R. Bennett, ${ }^{1,2}$ Scott J. Canavera, ${ }^{1}$ \\ Lee S. Newman, 1,3,4 and Brian L. Kotzin ${ }^{1,2,4}$ \\ ${ }^{1}$ Department of Medicine, \\ ${ }^{2}$ Department of Immunology, and \\ ${ }^{3}$ Department of Preventive Medicine and Biometrics, University of Colorado Health Sciences Center, Denver, Colorado, USA \\ ${ }^{4}$ Department of Medicine, National Jewish Medical and Research Center, Denver, Colorado, USA
}

\begin{abstract}
$T$ cell receptor engagement with $\mathrm{CD} 28$ costimulation is generally required for naive $\mathrm{T}$ cell activation, whereas reactivation of memory cells is less dependent on CD28 costimulation. We studied this process in chronic beryllium disease, in which the frequency of antigen-specific $\mathrm{CD} 4^{+} \mathrm{T}$ cells in the lung is large and circulating antigen-specific cells are also detectable. In the lung, a large fraction of $\mathrm{CD}^{+} \mathrm{T}$ cells stopped expressing CD28 mRNA and protein, and this change in phenotype correlated with lung inflammation. In the presence of concentrations of CTLA-4Ig that inhibited the CD28-B7 interaction, beryllium-specific $\mathrm{CD}^{+} \mathrm{T}$ cells in lung were still able to proliferate and secrete IFN- $\gamma$ in response to beryllium in culture. This functional independence of CD28 costimulation included lung $\mathrm{CD}^{2} 8^{+}$effector cells. Although lung $\mathrm{CD}^{+} \mathrm{CD} 28^{-}$cells retained the ability to secrete Th1-type cytokines in response to beryllium, they showed less proliferative capacity and were more susceptible to cell death compared with $\mathrm{CD} 28^{+} \mathrm{T}$ cells. In contrast to lung cells, inhibition of the CD28-B7 interaction markedly reduced responses of beryllium-specific $\mathrm{T}$ cells in blood. Taken together, these findings suggest transition within memory $\mathrm{CD}^{+} \mathrm{T}$ cells from $\mathrm{CD} 28$ dependence in central memory cells to functional independence and then loss of CD28 expression in effector cells.
\end{abstract}

J. Clin. Invest. 112:776-784 (2003). doi:10.1172/JCI200318317.

\begin{abstract}
Introduction
The differentiation of naive $\mathrm{T}$ cells into memory $\mathrm{T}$ cells is a crucial step in the evolution of an immune response. Optimal activation of naive $\mathrm{T}$ cells requires two signaling events $(1,2)$. Signal one is mediated by $\mathrm{T}$ cell receptor (TCR) engagement with antigen and MHC molecule on APCs. Signal two, termed costimulation, is most frequently mediated by the engagement of the CD28 molecule on the T cell with its ligands, B7-1 or $\mathrm{B} 7-2$, on the APC. In the absence of costimulation, engagement of TCR on naive T cells can result in an unresponsive state of clonal anergy $(3,4)$, and this clonal inactivation is believed to play an important role in the maintenance of peripheral $\mathrm{T}$ cell tolerance (5). In contrast to naive $\mathrm{T}$ cells, memory $\mathrm{T}$ cells can proliferate and secrete cytokines after TCR engagement without CD28-mediated costimulation (6-8).
\end{abstract}

Received for publication March 10, 2003, and accepted in revised form June 10, 2003

Address correspondence to: Andrew P. Fontenot, Division of Clinical Immunology (B164), University of Colorado Health Sciences Center, 4200 East Ninth Avenue, Denver, Colorado 80262, USA. Phone: (303) 315-7601; Fax: (303) 315-7642;

E-mail: andrew.fontenot@uchsc.edu.

Conflict of interest: The authors have declared that no conflict of interest exists.

Nonstandard abbreviations used: $\mathrm{T}$ cell receptor (TCR); chronic beryllium disease (CBD); bronchoalveolar lavage (BAL); staphylococcal enterotoxin B (SEB); white blood cell (WBC); myelin basic protein (MBP).
Previous studies in our laboratory have demonstrated that patients with chronic beryllium disease (CBD) accumulate large numbers of beryllium-specific $\mathrm{CD}^{+} \mathrm{T}$ cells in the lung (9), and this disease provides an opportunity to study the scope of antigen-specific memory cells in a human disease. Because of its desirable chemical and physical properties, beryllium continues to be used in many industries, and exposure to beryllium in the workplace remains an important public health concern (10, 11). Of the greater than one million individuals at risk for developing CBD, the disorder will develop in $1-16 \%$, depending on the nature of the exposure and the genetic susceptibility of the individual (10-16). CBD is characterized by the presence of granulomatous inflammation in the lung, and this disease is clinically and pathologically similar to a more common idiopathic disease, sarcoidosis $(17,18)$. Considerable evidence indicates that the accumulation and activation of beryllium-specific $\mathrm{CD} 4^{+}$ $\mathrm{T}$ cells in the lung is central to the pathogenesis of disease $(9,10,19,20)$. The ability of peripheral blood and/or bronchoalveolar lavage (BAL) $\mathrm{CD} 4^{+} \mathrm{T}$ cells to proliferate in the presence of beryllium salts in vitro forms part of the current disease definition of $\operatorname{CBD}(11,13,14,19,21$, 22 ). In the lung, the large majority of beryllium-specific $\mathrm{CD} 4^{+} \mathrm{T}$ cells express an effector-memory phenotype and demonstrate immediate release of Th1-type cytokines when stimulated with beryllium in culture $(9,23)$. The known identity of antigen and high frequency of antigenspecific cells distinguish CBD from other human conditions in terms of ability to study $\mathrm{T}$ cell responses. 
Here, we examined the role of CD28-mediated costimulation in antigen-specific $\mathrm{T}$ cell activation and survival. The results demonstrate an apparent evolution of independence from CD28-mediated costimulation that correlates with memory cell differentiation. Memory $\mathrm{CD}^{+} \mathrm{T}$ cells in blood continued to require CD28 costimulation for proliferative and cytokine responses to beryllium. In the lung, proliferation and secretion of Th1-type cytokines by effector memory cells were functionally independent of CD28 costimulation, and a proportion of these cells stopped expressing CD28. These CD4 ${ }^{+} \mathrm{CD} 28^{-} \mathrm{T}$ cells showed decreased proliferative capacity and an increased rate of apoptosis after stimulation with antigen, suggesting transition to a presenescent state.

\section{Methods}

Study population. Twelve patients with a diagnosis of CBD were enrolled in this study. The diagnosis of CBD was established using the following criteria: a history of beryllium exposure, the presence of granulomatous inflammation found as a result of a lung biopsy, and a positive proliferative response of blood and/or BAL $\mathrm{T}$ cells to $\mathrm{BeSO}_{4}$ in vitro $(10,11)$. A group of four sarcoidosis patients and nine healthy subjects served as negative control subjects. Informed consent was obtained from each CBD patient and control subject, and the protocol was approved by the Human Subject Institutional Review Boards at the University of Colorado Health Sciences Center and National Jewish Medical and Research Center.

Immunofluorescence staining and analysis of CD28 gene expression. PBMCs were isolated from heparinized blood by Ficoll-Hypaque (Amersham Pharmacia Biotech, Piscataway, New Jersey, USA) density-gradient separation, and BAL was performed as described previously (12, 24-26). PBMCs and BAL cells were stained with mAb's to CD4 and CD28 (both from Becton Dickinson Immunocytometry Systems, San Jose, California, USA). A subset of the BAL cells was labeled with CFSE as described (27). The lymphocyte population was identified using forward and 90-degree light-scatter patterns, and fluorescence intensity was analyzed using an FACScalibur cytometer (Becton Dickinson Immunocytometry Systems) as described previously (9).

In some experiments, CD28 gene expression was also analyzed by RT-PCR. BAL cells were stained for CD4 and $\mathrm{CD} 28$, and $\mathrm{CD}^{+} \mathrm{CD} 28^{+}$and $\mathrm{CD} 4^{+} \mathrm{CD} 28^{-}$cells were sorted using a MoFlo cell sorter (Cytomation Inc., Fort Collins, Colorado, USA). Equal numbers of cells of each subset were isolated and immediately frozen prior to preparation of total cellular RNA and cDNA. Sterile water and cDNA from a normal subject served as negative and positive controls for the RT-PCR, respectively. PCR amplification of a CD28 gene fragment was accomplished with the forward primer, $5^{\prime}$-AACAAGATTTTGGTGAAGCAGTCGCCC- 3 ', and the reverse primer, $5^{\prime}$-GTTCATGTAGTCACTGTGCAGGAGCCT- $3^{\prime}$, as described (28). As a control for an equal number of cells, a TCR BV3S1 gene segment was also amplified as described (28). PCR products were visualized electrophoretically on agarose gels.
Cell culture and immunofluorescence analysis for intracellular cytokine expression. Proliferation assays were performed as described previously $(9,12)$. In brief, BAL cells $\left(10^{5}\right.$ cells/well $)$ and PBMCs $\left(2.5 \times 10^{5}\right.$ cells/well $)$ were cultured in 96-well flat-bottom microtiter plates in the presence of $5 \mu \mathrm{g} / \mathrm{ml}$ PHA for 48 hours or $10^{-5} \mathrm{M}$ $\mathrm{BeSO}_{4}$ with or without the addition of various concentrations of CTLA-4Ig (R\&D Systems Inc., Minneapolis, Minnesota, USA) for 4 days. During the last 18 hours, the wells were pulsed with $1 \mu \mathrm{Ci}$ of $\left[{ }^{3} \mathrm{H}\right]$ thymidine, and incorporation of radioactivity was determined by $\beta$-emission spectroscopy. Proliferation assays were performed in triplicate.

For stimulation of cytokine secretion, BAL cells $\left(2.5 \times 10^{5}\right.$ to $5 \times 10^{5}$ cells $)$ or PBMCs $\left(10^{6}\right.$ cells $)$ were placed in $12 \times 75-\mathrm{mm}$ polypropylene tubes (Fisher Scientific Co., Pittsburgh, Pennsylvania, USA) containing $1 \mathrm{ml}$ of RPMI-1640 supplemented with $10 \%$ heat-inactivated human serum (Gemini Biological Products, Woodland, California, USA) and one of the following experimental conditions: medium alone, $10 \mathrm{ng} / \mathrm{ml}$ staphylococcal enterotoxin $\mathrm{B}(\mathrm{SEB})$, or $10^{-5} \mathrm{M} \mathrm{BeSO}_{4}$ with or without CTLA-4Ig. Cells were incubated for a total of 6 hours with $10 \mu \mathrm{g} / \mathrm{ml}$ brefeldin A added after the first hour of stimulation (9). After stimulation, cells were washed and stained with mAb's directed against CD4, CD8, and CD28 (all from Becton Dickinson Immunocytometry Systems). Cells were then washed with PBS containing $1 \%$ BSA and placed in fixation medium (Caltag Laboratories Inc., Burlingame, California, USA) for 15 minutes at room temperature. Following washing with PBS containing 1\% BSA, cells were added to permeabilization medium (Caltag Laboratories Inc.) and stained with a mAb directed against IFN- $\gamma$ or IL- 2 (both from Caltag Laboratories Inc.) for 30 minutes at $4^{\circ} \mathrm{C}(9)$. Flow-cytometric analysis was performed as described above.

The generation of the BAL T cell clones was performed as described previously (25). In brief, variable numbers of sorted $\mathrm{CD}^{+} \mathrm{T}$ cells and $10^{4}$ irradiated autologous EBV-transformed lymphoblastoid cells were cultured in 96-well microtiter plates (Falcon; Becton Dickinson Labware, Franklin Lakes, New Jersey, USA) in RPMI-1640 media (BioWhitaker Inc., Walkersville, Maryland, USA) supplemented with $10 \%$ heat-inactivated human serum (Gemini Biological Products), 20 mM HEPES, 100 U/ml penicillin, $100 \mu \mathrm{g} / \mathrm{ml}$ streptomycin, $2 \mathrm{mM}$ L-glutamine (all from Life Technologies Inc., Gaithersburg, Maryland, USA), and $10^{-5} \mathrm{M} \mathrm{BeSO}_{4}$. After 12-14 days, T cell colonies were transferred to 1 -ml cultures supplemented with $20 \mathrm{U} / \mathrm{ml}$ recombinant human IL-2 (R\&D Systems Inc.). The $\mathrm{T}$ cell clones were maintained in culture by cycles of restimulation every 2-4 weeks.

Apoptosis assay. BAL cells and BAL T cell clones from CBD patients were stimulated with either $20 \mathrm{U} / \mathrm{ml}$ of IL-2, 10 $\mathrm{ng} / \mathrm{ml} \mathrm{SEB}$, or $10^{-5} \mathrm{M} \mathrm{BeSO}_{4}$ for 24-48 hours. Rates of apoptosis were determined by staining with annexin $\mathrm{V}$ and propidium iodide (both from Molecular Probes Inc., Eugene, Oregon, USA), and the cells were immediately analyzed by flow cytometry as described above. 


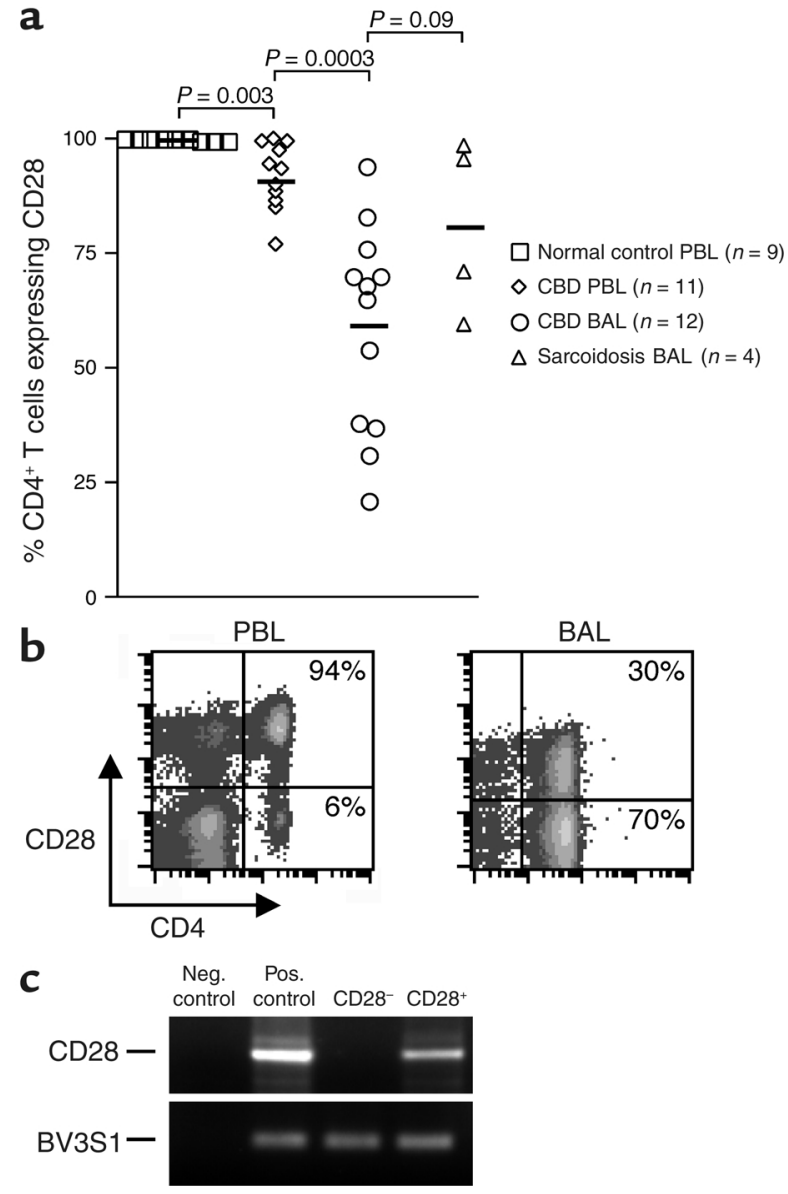

\section{Figure 1}

Expression of CD28 on the surface of $C D 4^{+} T$ cells from peripheral blood (PBL) and BAL. (a) The percentage of CD4 ${ }^{+} \mathrm{T}$ cells expressing CD28 in blood of normal control subjects, blood of CBD patients, BAL of CBD patients, and BAL of sarcoidosis patients is shown. The black bar represents the mean value for each disease group. (b) Representative flow-cytometric staining of blood and BAL CD4 $4^{+} \mathrm{T}$ cells from CBD patients for expression of CD28. The numbers in the upper- and lower-right quadrants are the percentages of $C D 4^{+} T$ cells staining positively and negatively for $\mathrm{CD} 28$ expression, respectively. (c) Expression of CD28 mRNA in BAL cells sorted into CD $4^{+} \mathrm{CD} 28^{+}$ and $\mathrm{CD} 4^{+} \mathrm{CD} 28^{-}$subsets. RNA was obtained from the sorted populations and then analyzed for expression of CD28 and the TCR V $\beta 3.1$ gene segment (TCR BV3S1) by RT-PCR. Neg., negative; Pos., positive.

\section{Results}

$C D 28$ expression on blood and BAL CD4 $4^{+}$Tells. Since a subset of $\mathrm{CD} 4^{+} \mathrm{T}$ cells has been reported to lose $\mathrm{CD} 28$ expression in certain other chronic inflammatory conditions (29-32), we initially analyzed CD28 expression on blood and BAL CD4 ${ }^{+} \mathrm{T}$ cells from $\mathrm{CBD}$ patients. Freshly isolated PBMCs and BAL cells were obtained from CBD patients and control subjects, and the percentage of $\mathrm{CD}^{+}$ T cells expressing CD28 was determined by immunofluorescence staining and cytofluorographic analysis. As shown in Figure 1a, nearly all CD4 ${ }^{+} \mathrm{T}$ cells from the blood of healthy control subjects express CD28 (mean \pm SE, $99.8 \% \pm 0.07 \%$ ). This frequency was significantly decreased in CBD patients $(92 \% \pm 2.2 \% ; P=0.003)$. The loss of CD28 expression was even more marked in the BAL, and the percentage of $\mathrm{CD}^{+} \mathrm{T}$ cells expressing $\mathrm{CD} 28$ ranged from $21 \%$ to $94 \%$ (mean \pm SE, $59 \% \pm 6.5 \% ; P=0.0003$, compared with $\mathrm{PBMCs}$ ). This loss was not specific to $\mathrm{CBD}$ since decreases were also noted in the BAL of sarcoidosis patients $(P=0.09$ compared with CBD). Analysis of the level of CD28 expression on negative cells by fluorescence intensity (Figure 1b) suggested that CD28 expression was absent, as opposed to partially downregulated. The essentially complete loss of $\mathrm{CD} 28$ expression was confirmed by analysis of $\mathrm{CD} 28 \mathrm{mRNA}$ in sorted $\mathrm{CD} 4{ }^{+} \mathrm{CD} 28^{+}$and $\mathrm{CD}^{+} \mathrm{CD} 28^{-}$populations (Figure $1 \mathrm{c}$ ).

Correlation between loss of CD28 and degree of inflammation in the lung. Based on the observation that the frequency of $\mathrm{CD} 4^{+} \mathrm{CD} 28^{-} \mathrm{T}$ cells in patients with rheumatoid arthritis was associated with the severity of disease $(31,33)$, we correlated the percentage of $\mathrm{BAL} \mathrm{CD} 4^{+} \mathrm{T}$ cells lacking $\mathrm{CD} 28$ expression with total BAL white blood cell (WBC), lymphocyte and macrophage counts in patients with CBD (Figure 2). Significant positive correlations were seen for both total BAL WBC count $\left(r^{2}=0.495 ; P=0.012\right)$ and lymphocyte count $\left(r^{2}=0.482 ; P=0.015\right)$. On the other hand, no correlation was observed between the frequency of BAL CD4 ${ }^{+} \mathrm{CD} 28^{-} \mathrm{T}$ cells and total BAL macrophage count $\left(r^{2}=0.031 ; P=0.52\right)$. Thus, the severity of the $\mathrm{CD}^{+}$ $\mathrm{T}$ cell alveolitis appears to be tied to the loss of $\mathrm{CD} 28$ expression on $\mathrm{CD}^{+} \mathrm{T}$ cells in the BAL.

$I F N-\gamma$ and $I L-2$ expression by BAL and peripheral blood $\mathrm{CD}^{+} \mathrm{T}$ cells after stimulation with $\mathrm{BeSO}_{4}$. Using intracellular IFN- $\gamma$ expression as a measure of response (9), BAL cells and PBMCs were cultured with $\mathrm{BeSO}_{4}$ at the optimal concentration of $10^{-5} \mathrm{M}$ for a total of 6 hours. Previous studies have shown that PBMCs from healthy individuals and disease controls, as well as BAL cells from sarcoidosis patients, demonstrate no response to $\mathrm{BeSO}_{4}$ in these assays, but do have the ability to be stimulated by SEB (9). In contrast, cells from CBD patients can show marked responses after the addition of $\mathrm{BeSO}_{4}$. A representative example of intracellular cytokine expression of BAL $\mathrm{CD}^{+}{ }^{+} \mathrm{T}$ cells from CBD patient 1 is shown in Figure 3a. We observed minimal background IFN- $\gamma$ staining in the absence of stimulation (medium alone). Following $\mathrm{BeSO}_{4}$ stimulation of fresh BAL cells from patient 1 , a greater frequency of $\mathrm{CD} 4{ }^{+} \mathrm{CD} 28^{+}$cells express IFN- $\gamma$ after $\mathrm{BeSO}_{4}$ exposure as compared with their CD28- counterparts (21\% versus $12 \%$ ) (Figure $3 a$ ). Among the 12 patients studied, the frequency of IFN- $\gamma-$ producing cells in the $\mathrm{CD} 4^{+} \mathrm{CD} 28^{-}$and $\mathrm{CD} 4^{+} \mathrm{CD} 28^{+}$ subsets was $11.3 \% \pm 3.3 \%$ and $18.9 \% \pm 3.6 \%(P=0.08)$, respectively (Figure 3c). Overall, only CBD patients 3 and 10 had a greater percentage of IFN- $\gamma$-producing cells in the $\mathrm{CD} 4^{+} \mathrm{CD} 28^{-}$population. On the other hand, SEB stimulated a larger number of cells to secrete IFN- $\gamma$, and the $\mathrm{CD}^{+}{ }^{+} \mathrm{CD} 28^{-}$and $\mathrm{CD} 4^{+} \mathrm{CD} 28^{+}$subsets each had about the same proportion (mean \pm SEM; $51.3 \pm 3.0$ versus $49.2 \pm 2.8$ ) of responsive cells (Figure $3 \mathrm{a}$ ).

Previous studies have shown that a subset of the IFN- $\gamma-$ expressing cells also produce IL-2 when stimulated by $\mathrm{BeSO}_{4}$ (9). Despite the importance of CD28 signaling 

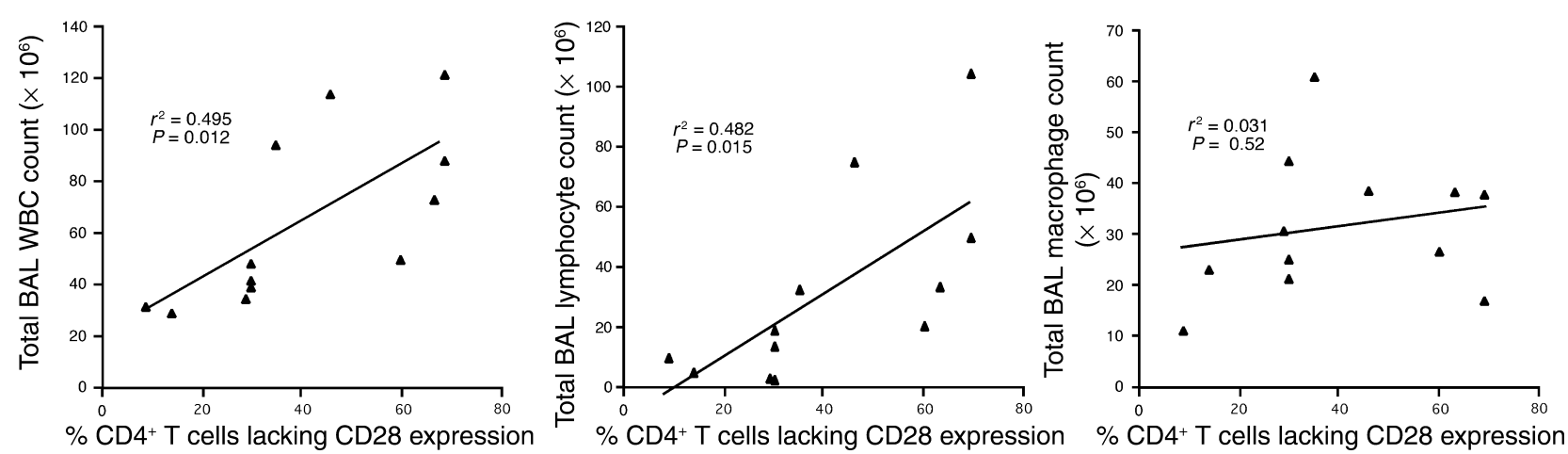

Figure 2

Correlation between the percentage of $C D 4^{+} T$ cells lacking $C D 28$ expression and total BAL WBC, lymphocyte, and macrophage cell counts in 12 CBD patients.

in IL-2 production $(34,35)$, a significant fraction of $\mathrm{CD} 4{ }^{+} \mathrm{CD} 28^{-} \mathrm{T}$ cells expressed IL-2, and levels appeared to be similar compared with $\mathrm{CD} 28^{+}$-secreting cells (Figure $3 \mathrm{~b})$. Among the $10 \mathrm{BAL}$ samples studied for IL-2 production, however, the percentage of $\mathrm{CD} 4^{+} \mathrm{CD} 28^{-}$ BAL cells that expressed IL-2 was significantly lower compared with the $\mathrm{CD} 4{ }^{+} \mathrm{CD} 28^{+}$cells $(4.3 \% \pm 1.1 \%$ versus $11.8 \% \pm 2.7 \% ; P=0.02$ ) (Figure $3 c$ ), and the ratio to IFN- $\gamma$-secreting cells was also lower in this subset (0.46 \pm 0.04 versus $0.68 \pm 0.04 ; P=0.001$ ).

We also analyzed the $\mathrm{CD} 28$ phenotype of $\mathrm{BeSO}_{4}$ responsive $\mathrm{CD}^{+} \mathrm{T}$ cells in the peripheral blood of patients with CBD. Previous studies showed that the frequency of peripheral blood IFN- $\gamma$ expressing $\mathrm{CD} 4^{+} \mathrm{T}$ cells after stimulation with $\mathrm{BeSO}_{4}$ ranged from undetectable to approximately 1 in 500 cells in CBD patients (9). For the current studies, we selected PBMC samples that proliferated in the presence of $\mathrm{BeSO}_{4}$ and had detectable cytokine-producing cells. One example is shown in Figure 4a. Following short-term culture with $\mathrm{BeSO}_{4}$, approximately 1 in 2,000 CD4 $4^{+} \mathrm{T}$ cells from patient 1 expressed IFN- $\gamma$. The beryllium-responsive cells were localized to the $\mathrm{CD} 28^{+} \mathrm{T}$ cell population, although this individual had a sizable percentage $(5.3 \%)$ of $\mathrm{CD} 4^{+} \mathrm{CD} 28^{-} \mathrm{T}$ cells in the blood. In the example shown, $61 \%$ of the $\mathrm{CD}^{+} \mathrm{CD}^{+} 8^{-}$

\section{Figure 3}

Intracellular staining for IFN- $\gamma$ and IL-2 in stimulated BAL T cells from CBD patients. Representative experiments are shown for the flow-cytometric analysis of BAL CD4 ${ }^{+} \mathrm{T}$ cells from CBD patient 1 (a) and patient 3 (b) stimulated with either medium alone, $\mathrm{BeSO}_{4}$, or SEB and subsequently stained for surface CD4 and CD28 and intracellular IFN- $\gamma$ or IL-2. BAL cells were gated on CD4 expression. The numbers in the upper-left and -right quadrants of each density plot are the percentages of $\mathrm{CD} 4^{+} \mathrm{CD} 28^{-}$and $\mathrm{CD} 4^{+} \mathrm{CD} 28^{+}$cells, respectively, that express IFN- $\gamma$ or IL-2. (c) Percentage of BAL CD4+CD28and $\mathrm{CD} 4{ }^{+} \mathrm{CD} 28^{+}$cells that express intracellular IFN- $\gamma$ and IL-2 after short-term stimulation with $\mathrm{BeSO}_{4}$. The mean percentage of Th1 cytokine produced by $\mathrm{CD} 4^{+} \mathrm{CD} 28^{-}$and $\mathrm{CD} 4^{+} \mathrm{CD} 28^{+}$cells from $\mathrm{CBD}$ patients is shown as a solid line: mean \pm SEM for IFN- $\gamma(n=12)$, $11.3 \% \pm 3.3 \%$ for $\mathrm{CD} 4{ }^{+} \mathrm{CD} 28^{-}$cells and $18.9 \% \pm 3.6 \%$ for CD $4^{+} \mathrm{CD} 28^{+}$cells; IL-2 $(n=10), 4.3 \% \pm 1.1 \%$ for $\mathrm{CD}^{+}{ }^{+} \mathrm{CD} 28^{-}$cells and $11.8 \% \pm 2.7 \%$ for $\mathrm{CD} 4{ }^{+} \mathrm{CD} 28^{+}$cells. cells expressed IFN- $\gamma$ after SEB stimulation compared with $10 \%$ of the $\mathrm{CD} 4^{+} \mathrm{CD} 28^{+} \mathrm{T}$ cells, yet essentially none (detection limit less than 1:2,000) of the $\mathrm{CD}^{+} \mathrm{CD} 28^{-}$cells expressed IFN- $\gamma$ following $\mathrm{BeSO}_{4}$ stimulation. Few, if any, IFN- $\gamma$-producing cells were detected in the $\mathrm{CD} 4^{+} \mathrm{CD} 28$ population of any of the four blood samples from CBD patients (Figure $4 \mathrm{~b}$ ), and the results indicated that this population was not greatly enriched for beryllium-specific effector cells. In these four CBD patients, the frequency of $\mathrm{CD}^{+}{ }^{+} \mathrm{CD} 28^{-} \mathrm{T}$ cells ranged from $1.4 \%$ to $10 \%$ (Figure $4 \mathrm{~b}$ ). Thus, it is possible that the small size of the $\mathrm{CD} 28^{-}$population in blood might have prevented the detection of rare responding cells.

Functional dependence on CD28 costimulation. We used inhibitory concentrations of CTLA-4Ig to test for the

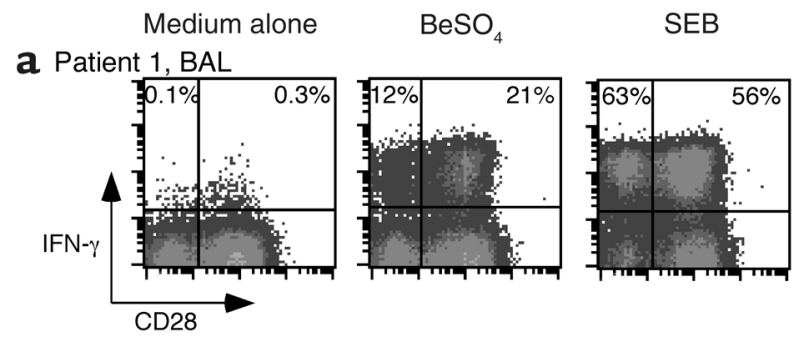

b Patient 3, BAL
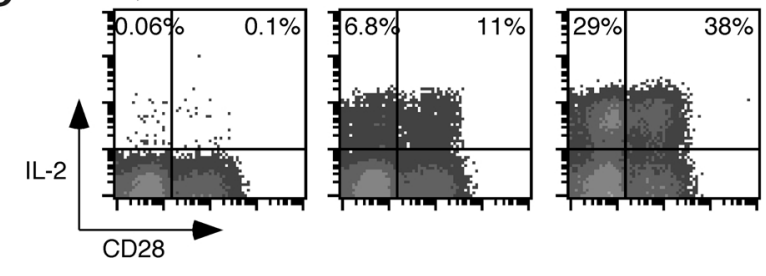

C

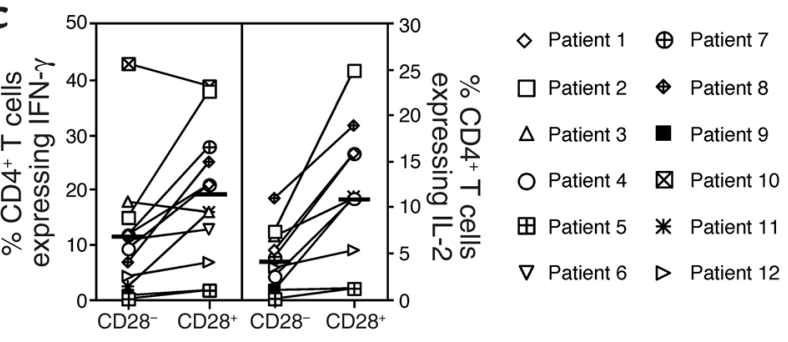




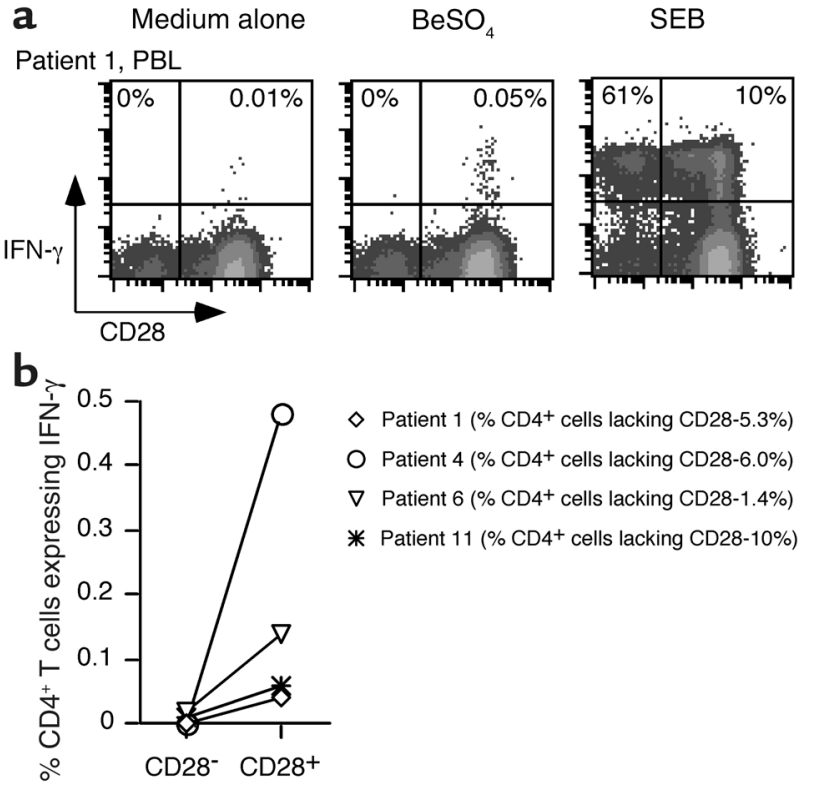

requirement of CD28-mediated costimulation when cells from CBD patients are stimulated with beryllium in culture. PBMCs from all CBD patients analyzed demonstrated a positive proliferative response (defined as a stimulation index of 2.5) in the presence of $10^{-5} \mathrm{M}$ $\mathrm{BeSO}_{4}$ (Figure 5a). For example, PBMCs from CBD patient 1 proliferated in response to $\mathrm{BeSO}_{4}$, with peak thymidine incorporation of $65,772 \pm 2173 \mathrm{cpm}$ compared with background proliferation of $431 \pm 165 \mathrm{cpm}$ (Figure 5a). Following the addition of $30 \mu \mathrm{g} / \mathrm{ml}$ CTLA-4Ig, beryllium-induced proliferation decreased 93\%. Among the seven patients studied, six demonstrated greater than $90 \%$ inhibition with this concen-

\section{Figure 4}

Intracellular staining for IFN- $\gamma$ in stimulated PBMCs from CBD patients. A representative experiment is shown for the flow-cytometric analysis of blood $\mathrm{CD}^{+} \mathrm{T}$ cells from $\mathrm{CBD}$ patient 1 (a) stimulated with either medium alone, $\mathrm{BeSO}_{4}$, or SEB, and stained for surface CD4 and CD28 and intracellular IFN- $\gamma$. Peripheral blood cells were gated for CD4 expression, and the numbers in the upper quadrants of each density plot are the percentages of $\mathrm{CD}^{+} \mathrm{CD} 28^{-}$and $\mathrm{CD} 4{ }^{+} \mathrm{CD} 28^{+}$cells that express IFN- $\gamma$. (b) Comparison of the frequency of $\mathrm{CD} 4{ }^{+} \mathrm{CD} 28^{-}$and $\mathrm{CD} 4^{+} \mathrm{CD} 28^{+}$cells that express IFN- $\gamma$ in fresh PBMCs from four CBD patients. The symbols for each CBD patient correspond to those shown in Figure 3.

tration of CTLA-4Ig (Figure 5a). The one exception, patient 7 , showed the lowest proliferative response, which was inhibited $35 \%$ with CTLA-4Ig.

BAL cells from five CBD patients were selected based on positive proliferative responses to $10^{-5} \mathrm{M} \mathrm{BeSO}_{4}$ in culture (Figure $5 \mathrm{~b}$ ). In contrast to the effects seen in peripheral blood, CTLA-4Ig had minimal, if any, inhibitory effects on the beryllium-induced proliferative response of BAL T cells. Only cells from patient 3 showed a $37 \%$ reduction in the proliferative response following the addition of $30 \mu \mathrm{g} / \mathrm{ml}$ CTLA- $4 \mathrm{Ig}$ (Figure $5 \mathrm{~b})$. In the remaining four patients, there was either no effect or enhancement of the proliferative response of BAL T cells when CTLA-4Ig was added to the culture.

Figure $5 \mathrm{c}$ shows the effects of varying concentrations of CTLA-4Ig on the proliferative responses of PBMCs and BAL cells. These studies again used optimal stimulatory concentrations of $\mathrm{BeSO}_{4}\left(10^{-5} \mathrm{M}\right)$. Proliferation of PBMCs was reproducibly inhibited with concentrations of CTLA-4Ig ranging from 0.3 to $30 \mu \mathrm{g} / \mathrm{ml}$ (Figures 5 , a and c). As shown in Figure $5 c, 0.3 \mu \mathrm{g} / \mathrm{ml}, 3$ $\mu \mathrm{g} / \mathrm{ml}$, and $30 \mu \mathrm{g} / \mathrm{ml}$ CTLA-4Ig inhibited the beryllium-

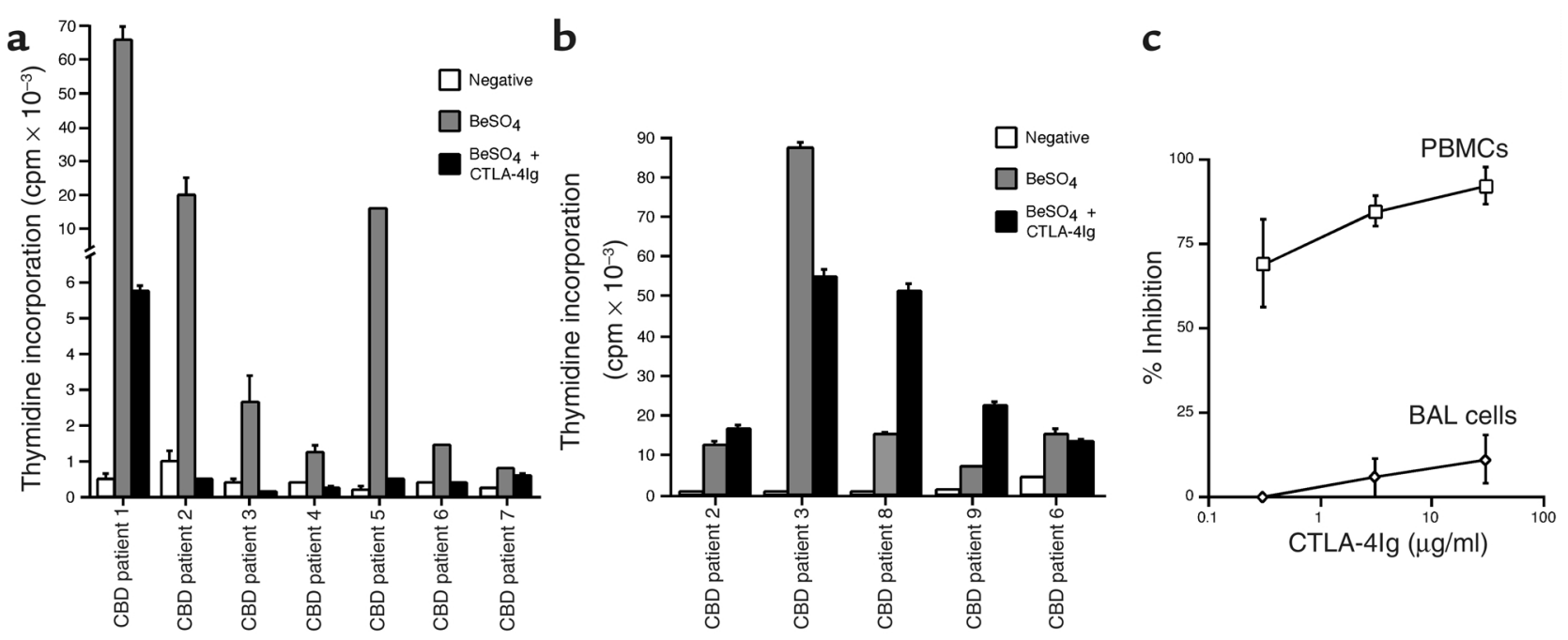

\section{Figure 5}

Proliferative responses of PBMCs (a) and BAL cells $(\mathbf{b})$ from CBD patients. Proliferation of the cells in medium alone and after the addition of $\mathrm{BeSO}_{4}$ with and without $30 \mu \mathrm{g} / \mathrm{ml}$ CTLA-4lg is shown. The data are expressed as the mean counts per minute \pm SEM. (c) Inhibition of the T cell proliferative responses of PBMCs and BAL cells to beryllium with various concentrations of CTLA-4lg. PBMCs $(n=7)$ and $\mathrm{BAL}$ cells $(n=5)$ from CBD patients were cultured with $10^{-5} \mathrm{M} \mathrm{BeSO}_{4}$ and increasing concentrations of CTLA-4lg. The data are expressed as the mean percentage inhibition of stimulation \pm SEM as a function of the concentration of CTLA-4Ig. 


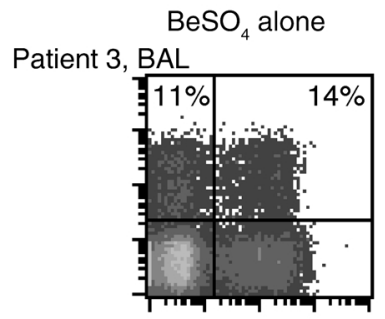

$\mathrm{BeSO}_{4}+\mathrm{CTLA}-4 \mathrm{Ig}$

Patient 6, BAL
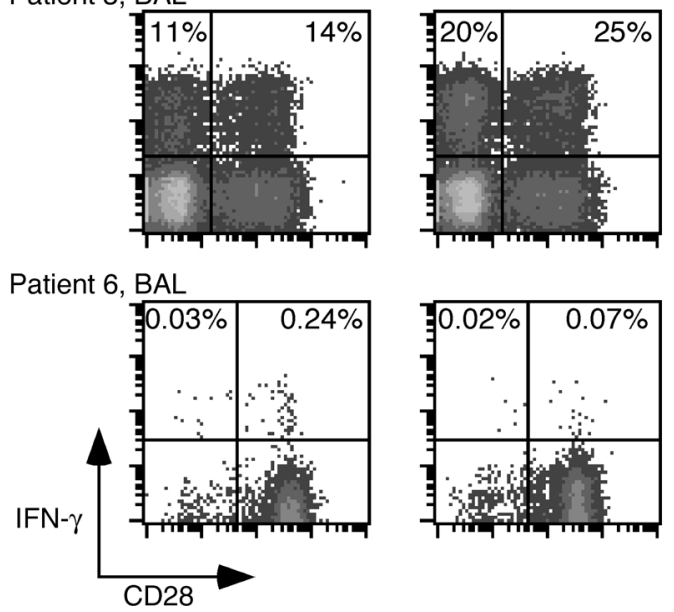

\section{Figure 6}

Intracellular expression of IFN- $\gamma$ after $\mathrm{BeSO}_{4}$ stimulation of BAL T cells and PBMCs from CBD patients with and without the addition of CTLA-4Ig. Representative experiments are shown for the flowcytometric analysis of BAL and blood $\mathrm{CD}^{+} \mathrm{T}$ cells from $\mathrm{CBD}$ patients 3 and 6 stimulated with $10^{-5} \mathrm{M} \mathrm{BeSO}_{4}$ and with or without $30 \mu \mathrm{g} / \mathrm{ml} \mathrm{CTLA}-4 \mathrm{lg}$. Cells were stained for surface CD4 and CD28 and intracellular IFN- $\gamma$ and then gated for $C D$ experssion. The expression of IFN- $\gamma$ after $\mathrm{BeSO}_{4}$ and CTLA-4Ig exposure in the blood of patient 6 was no greater than background staining $(0.06 \%)$. The numbers in the upper quadrants of each density plot are the percentages of $\mathrm{CD} 4^{+} \mathrm{CD} 28^{-}$and $\mathrm{CD} 4^{+} \mathrm{CD} 28^{+}$cells that express IFN- $\gamma$.

induced proliferative response $69 \% \pm 12.9 \%, 85 \% \pm 4.7 \%$, and $92 \% \pm 5.4 \%$, respectively. On the other hand, CTLA4Ig had little effect on proliferation of BAL T cells, with $0 \%$ inhibition when $0.3 \mu \mathrm{g} / \mathrm{ml}$ of CTLA-4Ig was added to the culture conditions. Studies described below show that the BAL $\mathrm{T}$ cell proliferative responses occurred in both the $\mathrm{CD} 4^{+} \mathrm{CD} 28^{+}$and $\mathrm{CD} 4^{+} \mathrm{CD} 28^{-}$populations; therefore, both populations were functionally independent of CD28 costimulation. These studies indicate that the beryllium-induced proliferative response in PBMCs occurs in a CD28-dependent manner, while in the lung, CD28-mediated costimulation is unnecessary.

We also determined what proportion of induced cytokine secretion in $\mathrm{BAL} \mathrm{CD} 4^{+}$cells was independent of CD28 costimulation. The addition of $30 \mu \mathrm{g} / \mathrm{ml}$ CTLA-4Ig had no inhibitory effect on IFN- $\gamma$ production induced in $\mathrm{BAL} \mathrm{CD} 4^{+} \mathrm{T}$ cells following short-term culture with $\mathrm{BeSO}_{4}$ (Figure 6). The lack of inhibition was equally apparent for both the $\mathrm{CD} 4{ }^{+} \mathrm{CD} 28^{+}$and $\mathrm{CD} 4^{+} \mathrm{CD} 28^{-}$populations with an enhancement of IFN- $\gamma$ expression with CTLA-4Ig in both populations. In addition to the findings shown for patient 3 in Figure 6 , $\mathrm{BAL} \mathrm{CD} 4^{+} \mathrm{CD} 28^{+}$and $\mathrm{CD} 4^{+} \mathrm{CD} 28^{-} \mathrm{T}$ cells from patient 8 showed a $21 \%$ and $9.6 \%$ increase in IFN- $\gamma$ expression after the addition of CTLA-4Ig. Similar findings were seen with 0.3 and $3 \mu \mathrm{g} / \mathrm{ml}$ CTLA-4Ig. Blockade of B7 molecules with CTLA-4Ig also resulted in enhanced beryllium-induced TNF- $\alpha$ production in both $\mathrm{CD} 28^{+}$ and $\mathrm{CD}^{-} 8^{-}$populations (data not shown).
Inhibition of cytokine secretion in stimulated PBMCs was more difficult to test because of the low frequency of antigen-specific cells in blood (9). In the peripheral blood of patient 6 , the frequency of beryllium-responsive $\mathrm{CD}^{+}$ $\mathrm{T}$ cells was approximately 1 in 415 (0.24\%), and the addition of $30 \mu \mathrm{g} / \mathrm{ml}$ CTLA- $4 \mathrm{Ig}$ decreased IFN- $\gamma$ expression after $\mathrm{BeSO}_{4}$ stimulation to background levels $(0.07 \%$ in the experiment shown in Figure 6). These studies therefore suggest that activation of beryllium-specific $\mathrm{CD}^{+} \mathrm{T}$ cells in blood, whether quantified by cytokine secretion or proliferation, is dependent on CD28 costimulation.

Proliferative capacity of $B A L C D 4^{+} T$ cells in relation to $C D 28$ expression. In preliminary studies, we noted an increased percentage of $\mathrm{CD}^{+} \mathrm{T}$ cells that expressed CD28 following 14 days of beryllium stimulation of BAL T cells (data not shown). These findings suggested that the $\mathrm{CD} 28^{+}$ BAL $T$ cells possess either a proliferative and/or a survival advantage following antigen-specific $\mathrm{T}$ cell activation. Using CFSE to track T cell division (27), we compared the proliferative capacity of $\mathrm{CD} 4^{+} \mathrm{CD} 28^{+}$and $\mathrm{CD} 4^{+} \mathrm{CD} 28^{-}$BAL $\mathrm{T}$ cells. After 5 days of beryllium exposure, $41 \%$ of the $\mathrm{CD} 4^{+} \mathrm{CD} 28^{+} \mathrm{T}$ cells underwent at least one cell division compared with $29 \%$ of the $\mathrm{CD} 4{ }^{+} \mathrm{CD} 28$ $\mathrm{T}$ cells (Figure $7 \mathrm{a}$ ). Prior to culture, $30 \%$ of the $\mathrm{CD}^{+} \mathrm{T}$
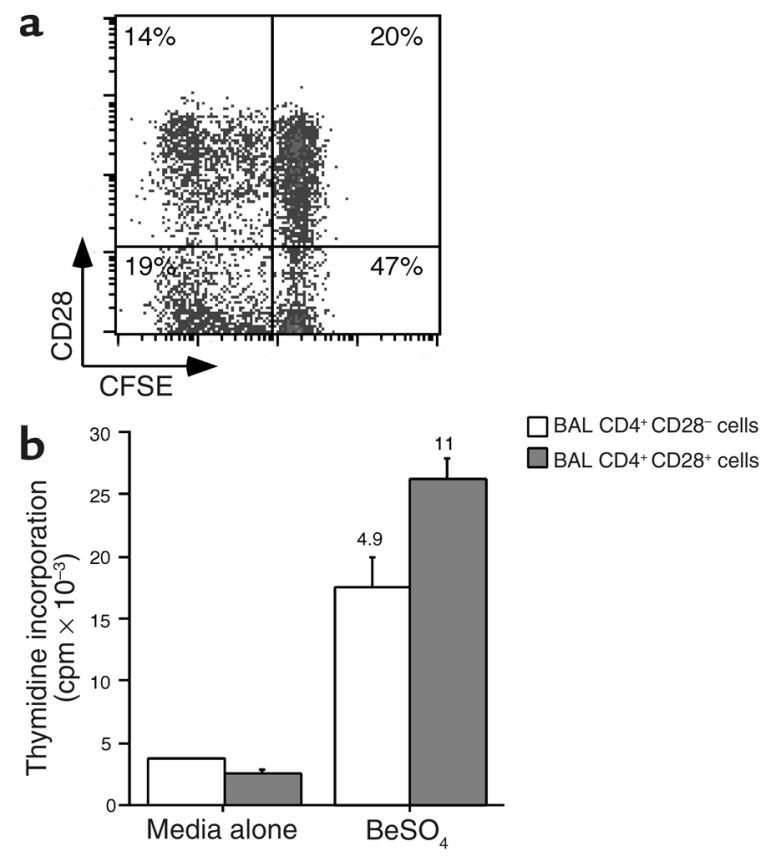

Figure 7

Differences in beryllium-specific BAL CD4 ${ }^{+} T$ cell proliferation between cells with and without CD28 expression. (a) A representative example of the proliferation in CFSE-labeled BAL CD4 ${ }^{+}$T cells after 5 days of culture in the presence of $10^{-5} \mathrm{M} \mathrm{BeSO}_{4}$ is shown. Proliferation is measured by a $50 \%$ decrease in fluorescence intensity of CFSE-labeled cells with each division. BAL cells were gated for CD4 expression, and the number in each quadrant of the density plot represents the percentage of $\mathrm{CD}^{+}{ }^{+} \mathrm{T}$ cells. (b) Proliferation of sorted $\mathrm{CD} 4^{+} \mathrm{CD} 28^{+}$and $\mathrm{CD} 4^{+} \mathrm{CD} 28^{-}$cells from $\mathrm{CBD}$ patient 3 in medium alone and after the addition of $10^{-5} \mathrm{M} \mathrm{BeSO}_{4}$ is shown. The data are expressed as the mean counts per minute \pm SEM, and the stimulation index for each proliferative response is shown over the corresponding bar. 

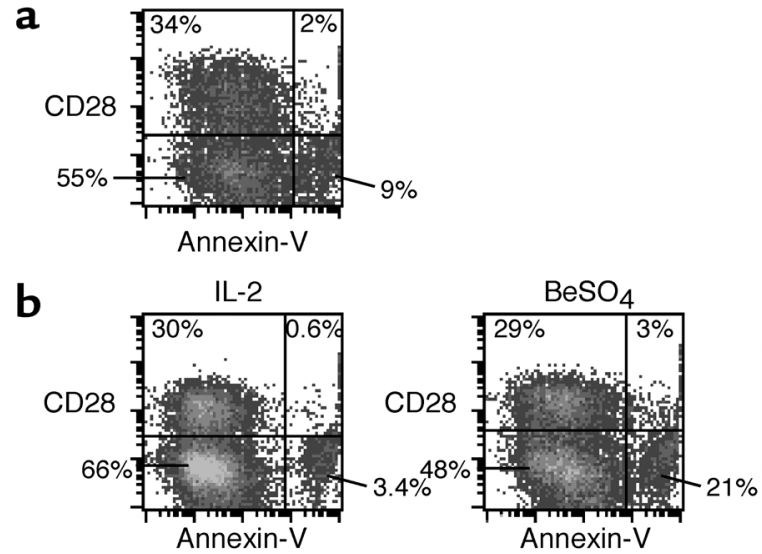

\section{Figure 8}

BAL CD4 ${ }^{+} \mathrm{CD} 28^{+} \mathrm{T}$ cells are relatively resistant to beryllium-induced cell death. Data are shown for representative experiments using fresh BAL cells (a) and T cell clones derived from the lung of CBD patient 12 (b) stimulated with either $20 \mathrm{U} / \mathrm{ml} \mathrm{IL}-2$ or $\mathrm{BeSO}_{4}$. Following 24-48 hours of culture, cells were stained for CD4, CD28, annexin $\mathrm{V}$, and propidium iodide. BAL cells were gated for CD4 expression, and the number in each quadrant of the density plots represents the percentage of $\mathrm{CD} 4^{+} \mathrm{T}$ cells.

cells expressed CD28, compared with 34\% 5 days after beryllium stimulation. Based on the similar frequencies of $\mathrm{CD} 28^{+}$and $\mathrm{CD} 28^{-} \mathrm{T}$ cells before and after $\mathrm{T}$ cell stimulation, it seemed unlikely that beryllium-specific $\mathrm{CD}_{28}{ }^{+} \mathrm{T}$ cells lost $\mathrm{CD} 28$ expression during culture. In separate experiments, BAL T cells were sorted into two populations, $\mathrm{CD}^{+}{ }^{+} \mathrm{CD} 28^{+}$and $\mathrm{CD} 4^{+} \mathrm{CD} 28^{-}$, prior to culture with autologous APCs and $\mathrm{BeSO}_{4}$. A strong proliferative response was induced in both populations of $\mathrm{T}$ cells (representative example shown in Figure 7b). The proliferative response (stimulated minus background proliferation), however, of the $\mathrm{CD} 4^{+} \mathrm{CD} 28^{-}$cells was $58 \%$ of the level of $\mathrm{CD} 4^{+} \mathrm{CD} 28^{+} \mathrm{T}$ cells.

Activation-induced apoptosis of $B A L C D 4^{+} T$ cells in relation to $C D 28$ expression. We also studied whether the berylliumspecific $\mathrm{CD} 4^{+} \mathrm{CD} 28^{-} \mathrm{T}$ cells in lung may be more susceptible to activation-induced cell death compared with their $\mathrm{CD} 28^{+}$counterparts. Fresh BAL cells and BAL-derived T cell clones were stimulated with $\mathrm{BeSO}_{4}$ for 24 hours, and the $\mathrm{CD} 4^{+} \mathrm{CD} 28^{+}$and $\mathrm{CD} 4^{+} \mathrm{CD} 28^{-}$subsets were stained with annexin $V$ and propidium iodide to determine the fraction of apoptotic cells (representative experiments are shown in Figure 8). Minimal annexin $V$ staining was seen on fresh BAL cells after culture with $20 \mathrm{U} / \mathrm{ml}$ of IL-2 for 24 hours (data not shown). After 24-hour stimulation with beryllium, $5.5 \%$ and $14 \%$ of the $\mathrm{CD} 4{ }^{+} \mathrm{CD} 28^{+}$and $\mathrm{CD} 4{ }^{+} \mathrm{CD} 28^{-}$subsets, respectively, expressed annexin $\mathrm{V}$ (Figure 8a). Using a beryllium-specific $\mathrm{T}$ cell clone derived from CBD patient 12 , the fraction of apoptotic cells in the $\mathrm{CD} 4{ }^{+} \mathrm{CD} 28^{+}$and the $\mathrm{CD} 4{ }^{+} \mathrm{CD} 28^{-}$subsets were $2 \%$ and $4.9 \%$, respectively, in cultures with IL-2. We observed a dramatic increase in apoptotic cells to $30 \%$ of the $\mathrm{CD} 4{ }^{+} \mathrm{CD} 28^{-}$subset after culture with $\mathrm{BeSO}_{4}$, compared with $9.4 \%$ of the $\mathrm{CD}^{+} \mathrm{CD} 28^{+}$subset (Figure $8 \mathrm{~b}$ ). The increased frequency of apoptotic cells in the $\mathrm{CD} 4^{+} \mathrm{CD} 28$ subset was observed in all three experiments in which it was studied and indicated the increased susceptibility of this subset to activation-induced cell death.

\section{Discussion}

We used patients with CBD to investigate the role of $\mathrm{CD} 28$-mediated costimulation in human memory $\mathrm{CD} 4^{+}$ $\mathrm{T}$ cell subsets. Large numbers of beryllium-specific $\mathrm{CD}^{+}$ $T$ cells are compartmentalized within the lungs of these subjects (9). These cells proliferate and rapidly secrete Th1type cytokines following recognition of beryllium bound to HLA-DP molecules on the surface of APCs $(9,12,23$, 36). Previous experiments have also shown that these cells have the phenotype of effector-memory cells, including the lack of surface CCR7 and CD62L expression (9). The current studies indicate that activation of these lung cells is independent of CD28-mediated costimulation. Indeed, a large proportion of BAL antigen-specific cells lost expression of CD28 at both the protein and mRNA levels, but continued to respond in culture. In contrast, the proliferative and cytokine responses of beryllium-specific $\mathrm{T}$ cells in blood were markedly inhibited by CTLA4-Ig, strongly suggesting a need for CD28-mediated costimulation. Although some CD28- cells were present in blood, few, if any, beryllium-specific cells could be demonstrated in this subset. Taken together, these studies suggest that a decreased reliance on CD28-mediated costimulation is not a universal phenomenon among all memory $\mathrm{CD}^{+} \mathrm{T}$ cells and that functionally distinct memory subsets may be distinguished by $\mathrm{CD} 28$ function and expression.

The loss of CD28 on a subset of activated $\mathrm{CD}^{+} \mathrm{T}$ cells has been described in several chronic inflammatory disorders, such as sarcoidosis, rheumatoid arthritis, multiple sclerosis, type 1 diabetes, and chronic infection $(29-32,37)$. It has also been observed in elderly individuals (38). Although most of these studies have focused on peripheral blood cells, downregulation of CD28 expression has also been observed on BAL cells from patients with sarcoidosis, a pathologically similar lung disease (37). In studies of CD28- cells in rheumatoid arthritis, the decreased surface CD28 was similarly associated with a loss of gene expression $(31,38,39)$. What signals the cell to alter its CD28 gene expression is not known. The lungs in both CBD and sarcoidosis are characterized by an accumulation of activated $\mathrm{CD} 4^{+} \mathrm{T}$ cells that secrete Th1-type cytokines $(9,23,37)$. The positive correlation between the loss of CD28 expression on $\mathrm{CD} 4^{+} \mathrm{T}$ cells and the magnitude of the $\mathrm{T}$ cell alveolitis suggests that prolonged Th1-type cytokine exposure might be the underlying mechanism. Support for this idea includes the observation that exposure of $\mathrm{CD}^{+} \mathrm{T}$ cells to increasing concentrations of TNF- $\alpha$ resulted in decreased CD28 expression and even CD28 $8^{\text {null }}$ cells after 8 weeks of continuous TNF- $\alpha$ exposure in culture (40). Furthermore, in the present studies, the loss of CD28 extended to cells that are not responsive to beryllium in our assay systems. Indeed, beryllium-specific cells were only a relatively small fraction of CD28 cells in the lung 
and were absent or rarely present in the blood CD28 cells. On the other hand, the blood $\mathrm{CD} 28^{-}$cells were capable of secreting Th1-type cytokines following superantigen stimulation, indicating that they are not anergic.

The loss of CD28 expression has been extensively described in $\mathrm{CD}^{+}$cells, especially in chronic infection and in elderly individuals that harbor clonal expansions $(28,41-45)$. In these studies, the loss of CD28 more clearly has been shown to be associated with differentiation to effector memory $\mathrm{CD}^{+}$cells. For example, in one study of functional subsets within individually expanded $\mathrm{CD}^{+}$clones, loss of $\mathrm{CD} 28$ was associated with increased perforin expression and loss of proliferative potential (28). We were unable to detect increased perforin expression in the BAL CD4 ${ }^{+} \mathrm{CD} 28^{-}$cells of $\mathrm{CBD}$ patients (data not shown). Studies of $\mathrm{CD}^{+}$clonal expansions have also clearly demonstrated that the CD28- cells derive from $\mathrm{CD} 28^{+}$cells (28), and it seems likely that the lung beryllium-specific CD28 cells in CBD patients also arise from $\mathrm{CD} 28^{+}$precursors, especially based on the mechanistic studies described above (40). Interestingly, loss of CD28 expression is apparently not a feature of $\mathrm{CD}^{+}$or $\mathrm{CD} 8^{+}$ memory $\mathrm{T}$ cell differentiation in mice (P. Marrack, personal communication), thus this phenomenon has not been studied in nonhuman systems.

Similar to studies of $\mathrm{CD}^{+} \mathrm{T}$ cells, we also noted decreased proliferation of $\mathrm{CD} 4^{+} \mathrm{CD} 28^{-}$compared with $\mathrm{CD} 4{ }^{+} \mathrm{CD} 28^{+}$cells after stimulation with antigen, despite maintained effector function. Consistent with this finding, CD28-mediated costimulation lowers the anti-CD3 concentration necessary to induce $T$ cell proliferation in vitro (34) and promotes cell cycle progression and IL-2 production, both of which are required for a sustained $\mathrm{T}$ cell response (2). The current studies are the first to suggest that loss of CD28 on human memory $\mathrm{CD}^{+}$cells is associated with susceptibility to activation-induced cell death. Our results are, however, consistent with previous studies that have implicated CD28 costimulation in enhanced $\mathrm{T}$ cell survival. This effect may be mediated through the enhanced production of IL-2 and increased expression of the antiapoptotic molecule, Bcl-xL (46). CD28-costimulated cells have also been shown to be less dependent on extrinsic growth factor (e.g., IL-2) for their ability to survive in culture (46). Recent studies also suggest that the CD28 signaling pathway affects the regulation of glucose metabolism (47), which also may be important in the prolonged survival of activated $\mathrm{T}$ cells. In a target organ characterized by persistent antigen exposure and continuous $\mathrm{T}$ cell activation, it is conceivable that the loss of CD28 on a metabolically active $T$ cell limits access to nutrients and marks the differentiation of these cells into presenescent state.

We also noted that the addition of CTLA-4Ig actually enhanced proliferation and cytokine production of beryllium-specific cells in lung in a number of different experiments. In studies quantifying intracellular cytokine expression, this enhancement occurred in both the $\mathrm{CD} 28^{-}$and $\mathrm{CD} 28^{+}$populations. These results seem most likely related to the ability of CTLA-4Ig to block the interaction of CTLA-4 (induced on the T cell after activation) with B7 on the APC, an interaction that usually leads to a downregulatory signal $(2,48,49)$. In preliminary experiments, CTLA-4 is upregulated following beryllium stimulation in both $\mathrm{CD} 4^{+} \mathrm{CD} 28^{+}$and $\mathrm{CD} 4^{+} \mathrm{CD} 28^{-} \mathrm{BAL} \mathrm{T}$ cells (A. Fontenot and B. Kotzin, unpublished data). It is noteworthy that our studies show that CTLA-4 may modulate the immediate cytokine production that occurs in these reactions.

Remarkable in the current study was the continued dependence of peripheral blood $\mathrm{CD} 4^{+}$cells on CD28 costimulation for both proliferative and cytokine responses to beryllium in culture. These findings contrast with studies of one group of investigators that have studied responses to the recall antigen, tetanus toxoid, and to certain autoantigens in multiple sclerosis (29) and type 1 diabetes (50). For example, in multiple sclerosis, myelin basic protein-reactive (MBP-reactive) T cells in the blood were found to be less dependent on CD28 costimulation for $\mathrm{T}$ cell proliferation as compared with MBP-specific T cells from healthy control subjects (29). Similar findings with respect to glutamic acid decarboxylase 65 -reactive $\mathrm{T}$ cells in type 1 diabetes have also been described (50). The explanation for the difference in findings is not known. Although Th2-versus Th1-type cells have been described to be more dependent on CD28 costimulation, our cells are almost all Th1 type, as in the above studies. Furthermore, although different reagents were used to test for CD28 dependence, we believe that it is unlikely that the CTLA-4Ig used in our studies could have inhibited through a mechanism other than blocking the CD28-B7 interaction (49). The different findings may relate to the recirculation of effector cells in blood in the different diseases being studied. Our previous studies have shown that the lung effector cells in CBD patients do not circulate in large numbers $(9,25)$. The remarkable compartmentalization of beryllium-specific cells in the lung may be related to the fact that antigen stimulation is only occurring in the lung. It is possible that differences in where antigen stimulation takes place compared with $\mathrm{CBD}$, or the timing of systemic antigen stimulation in relation to sampling, is key to whether circulating antigen-specific cells are dependent on $\mathrm{CD} 28$ costimulation. In this regard, we have noted that patch testing with beryllium leads to a large influx of antigen-specific cells into the blood within a few weeks, and these cells more closely resemble the lung $\mathrm{CD}^{+}$effector cells in terms of TCR expression (26). Whether these cells might also be independent of CD28 costimulation is currently unknown.

The current results extend the paradigm that memory $\mathrm{CD} 4^{+} \mathrm{T}$ cells are relatively independent of $\mathrm{CD} 28-$ mediated costimulation and have implications for therapies directed at the CD28-B7 interaction, for example, CTLA4-Ig or anti-B7. The results indicate that there is a transition within memory $T$ cell subsets from $\mathrm{CD} 28$ dependence in circulating cells, which are mostly central memory cells, to CD28 independence in fully differentiated effector memory cells. The need to block at the level of naive and early memory populations 
emphasizes that the accumulation of effector cells in the target organ may preclude therapeutic efficacy with these agents. Furthermore, the ability to target circulating memory cells may be extremely important for this therapeutic strategy to work. Finally, one may need to be cautious when using this therapy in diseases where large numbers of effector cells have accumulated in the target organ, since enhancement of the pathologic response is possible before benefit may take place.

\section{Acknowledgments}

This work was supported by the following NIH grants: HL62410, HL03982, ES06358, and P01ES011810, and the General Clinical Research Center (M01-RR-0051) from the Division of Research Resources.

1. Bretscher, P., and Cohn, M. 1970. A theory of self-nonself discrimination. Science. 169:1042-1049.

2. Bluestone, J.A. 1995. New perspectives of CD28-B7-mediated T cell costimulation. Immunity. 2:555-559.

3. Harding, F.A., McArthur, J.G., Gross, J.A., Raulet, D.H., and Allison, J.P. 1992. CD28-mediated signaling co-stimulates murine $T$ cells and prevents induction of anergy in T-cell clones. Nature. 356:607-609.

4. Schwartz, R.H. 1990. A cell culture model for T lymphocyte clonal anergy. Science. 248:1349-1356.

5. Liu, Y., and Janeway, C.A., Jr. 1992. Cells that present both specific ligand and costimulatory activity are the most efficient inducers of clonal expansion of normal CD4 T cells. Proc. Natl. Acad. Sci. U. S. A. 89:3845-3849.

6. Croft, M., Bradley, L.M., and Swain, S.L. 1994. Naive versus memory CD4 $\mathrm{T}$ cell response to antigen. Memory cells are less dependent on accessory cell costimulation and can respond to many antigen-presenting cell types including resting B cells. J. Immunol. 152:2675-2685.

7. Garcia, S., DiSanto, J., and Stockinger, B. 1999. Following the development of a CD4 T cell response in vivo: from activation to memory formation. Immunity. 11:163-171.

8. London, C.A., Lodge, M.P., and Abbas, A.K. 2000. Functional responses and costimulator dependence of memory CD4+ T cells. J. Immunol. 164:265-272.

9. Fontenot, A.P., Canavera, S.J., Gharavi, L., Newman, L.S., and Kotzin, B.L. 2002. Target organ localization of memory $\mathrm{CD} 4^{+} \mathrm{T}$ cells in patients with chronic beryllium disease. J. Clin. Invest. 110:1473-1482. doi:10.1172/ JCI200215846

10. Fontenot, A.P., Newman, L.S., and Kotzin, B.L. 2001. Chronic beryllium disease: $\mathrm{T}$ cell recognition of a metal presented by HLA-DP. Clin. Immunol. 100:4-14.

11. Newman, L.S., Maier, L.A., and Nemery, B. 1998. Interstitial lung disorders due to beryllium and cobalt. In Interstitial lung disease. 3rd edition. M.I. Schwarz and T.E. King, Jr., editors. B.C. Decker Inc. Hamilton, Ontario, Canada. 367-392.

12. Fontenot, A.P., Torres, M., Marshall, W.H., Newman, L.S., and Kotzin, B.L. 2000. Beryllium presentation to $\mathrm{CD} 4^{+} \mathrm{T}$ cells underlies disease susceptibility HLA-DP alleles in chronic beryllium disease. Proc. Natl. Acad. Sci. U. S. A. 97:12717-12722.

13. Kreiss, K., Wasserman, S., Mroz, M.M., and Newman, L.S. 1993. Beryllium disease screening in the ceramics industry: blood test performance and exposure-disease relations. J. Occup. Med. 35:267-274.

14. Kreiss, K., Mroz, M.M., Zhen, B., Martyny, J.W., and Newman, L.S. 1993. Epidemiology of beryllium sensitization and disease in nuclear workers. Am. Rev. Respir. Dis. 148:985-991.

15. Richeldi, L., et al. 1997. Interaction of genetic and exposure factors in the prevalence of berylliosis. Am. J. Ind. Med. 32:337-340.

16. Wang, Z., et al. 1999. Differential susceptibilities to chronic beryllium disease contributed by different Glu69 HLA-DPB1 and -DPA1 alleles. J. Immunol. 163:1647-1653.

17. Newman, L.S., and Kreiss, K. 1992. Nonoccupational beryllium disease masquerading as sarcoidosis: identification by blood lymphocyte proliferation response to beryllium. Am. Rev. Respir. Dis. 145:1212-1214.

18. Newman, L.S., Rose, C.S., and Maier, L.A. 1997. Sarcoidosis. N. Engl.J. Med. 336:1224-1234.

19. Rossman, M.D., et al. 1988. Proliferative response of bronchoalveolar lymphocytes to beryllium. Ann. Intern. Med. 108:687-693.

20. Saltini, C., Winestock, K., Kirby, M., Pinkston, P., and Crystal, R.G. 1989. Maintenance of alveolitis in patients with chronic beryllium disease by beryllium-specific helper T cells. N. Engl. J. Med. 320:1103-1109.

21. Kreiss, K., Newman, L.S., Mroz, M., and Campbell, P.A. 1989. Screening blood test identifies subclinical beryllium disease. J. Occup. Med. 31:603-608.
22. Mroz, M.M., Kreiss, K., Lezotte, D.C., Campbell, P.A., and Newman, L.S 1991. Reexamination of the blood lymphocyte transformation test in the diagnosis of chronic beryllium disease. J. Allergy Clin. Immunol. 88:54-60.

23. Tinkle, S.S., Kittle, L.A., Schumacher, B.A., and Newman, L.S. 1997. Beryllium induces IL-2 and IFN- $\gamma$ in berylliosis. J. Immunol. 158:518-526.

24. Fontenot, A.P., Kotzin, B.L., Comment, C., and Newman, L.S. 1998. Expansions of T-cell subsets expressing particular $\mathrm{T}$ cell receptor variable regions in chronic beryllium disease. Am. J. Respir. Cell Mol. Biol. 18:581-589.

25. Fontenot, A.P., Falta, M.T., Freed, B.M., Newman, L.S., and Kotzin, B.L. 1999. Identification of pathogenic T cells in patients with berylliuminduced lung disease. J. Immunol. 163:1019-1026.

26. Fontenot, A.P., et al. 2002. Beryllium skin patch testing to analyze T cell stimulation and granulomatous inflammation in the lung. J. Immunol. 168:3627-3634

27. Lyons, A.B., and Parish, C.R. 1994. Determination of lymphocyte division by flow cytometry. J. Immunol. Methods. 171:131-137.

28. Chamberlain, W.D., Falta, M.T., and Kotzin, B.L. 2000. Functional subsets within clonally expanded CD8(+) memory T cells in elderly humans. Clin. Immunol. 94:160-172.

29. Lovett-Racke, A.E., et al. 1998. Decreased dependence of myelin basic protein-reactive T cells on CD28-mediated costimulation in multiple sclerosis patients. A marker of activated/memory $\mathrm{T}$ cells. J. Clin. Invest. 101:725-730.

30. Markovic-Plese, S., Cortese, I., Wandinger, K.P., McFarland, H.F., and Martin, R. 2001. CD4+CD28- costimulation-independent T cells in multiple sclerosis. J. Clin. Invest. 108:1185-1194. doi:10.1172/JCI200112516.

31. Schmidt, D., Goronzy, J.J., and Weyand, C.M. 1996. CD4+CD7-CD28- T cells are expanded in rheumatoid arthritis and are characterized by autoreactivity. J. Clin. Invest. 97:2027-2037.

32. Haffar, O.K., et al. 1993. Costimulation of T-cell activation and virus production by $\mathrm{B} 7$ antigen on activated CD4+ T cells from human immunodeficiency virus type 1 -infected donors. Proc. Natl. Acad. Sci. U. S. A. 90:11094-11098.

33. Martens, P.B., Goronzy, J.J., Schaid, D., and Weyand, C.M. 1997. Expansion of unusual CD4+ T cells in severe rheumatoid arthritis. Arthritis Rheum. 40:1106-1114.

34. Gimmi, C.D., et al. 1991. B-cell surface antigen B7 provides a costimulatory signal that induces $\mathrm{T}$ cells to proliferate and secrete interleukin-2. Proc. Natl. Acad. Sci. U. S. A. 88:6575-6579.

35. Jenkins, M.K., Taylor, P.S., Norton, S.D., and Urdahl, K.B. 1991. CD28 delivers a costimulatory signal involved in antigen-specific IL-2 production by human T cells. J. Immunol. 147:2461-2466.

36. Lombardi, G., et al. 2001. HLA-DP allele-specific T cell responses to beryllium account for DP-associated susceptibility to chronic beryllium disease. J. Immunol. 166:3549-3555.

37. Katchar, K., Wahlstrom, J., Eklund, A., and Grunewald, J. 2001. Highly activated T-cell receptor AV2S3(+) CD4(+) lung T-cell expansions in pulmonary sarcoidosis. Am. J. Respir. Crit. Care Med. 163:1540-1545.

38. Vallejo, A.N., Nestel, A.R., Schirmer, M., Weyand, C.M., and Goronzy, J.J. 1998. Aging-related deficiency of CD28 expression in CD4+ T cells is associated with the loss of gene-specific nuclear factor binding activity. J. Biol. Chem. 273:8119-8129.

39. Vallejo, A.N., et al. 2002. Molecular basis for the loss of CD28 expression in senescent cells. J. Biol. Chem. 277:46940-46949.

40. Bryl, E., Vallejo, A.N., Weyand, C.M., and Goronzy, J.J. 2001. Down-regulation of CD28 expression by TNF-alpha. J. Immunol. 167:3231-3238.

41. Posnett, D.N., Sinha, R., Kabak, S., and Russo, C. 1994. Clonal populations of T cells in normal elderly humans: the T cell equivalent to "benign monoclonal gammapathy". J. Exp. Med. 179:609-618.

42. Azuma, M., Phillips, J.H., and Lanier, L.L. 1993. CD28- T lymphocytes. Antigenic and functional properties. J. Immunol. 150:1147-1159.

43. Fitzgerald, J.E., et al. 1995. Analysis of clonal $\mathrm{CD}^{+} \mathrm{T}$ cell expansions in normal individuals and patients with rheumatoid arthritis. J. Immunol. 154:3538-3547.

44. Weekes, M.P., Carmichael, A.J., Wills, M.R., Mynard, K., and Sissons, J.G. 1999. Human CD28-CD8+ T cells contain greatly expanded functional virus-specific memory CTL clones. J. Immunol. 162:7569-7577.

45. Appay, V., et al. 2002. Memory $\mathrm{CD}^{+} \mathrm{T}$ cells vary in differentiation phenotype in different persistent virus infections. Nat. Med. 8:379-385.

46. Boise, L.H., et al. 1995. CD28 costimulation can promote T cell survival by enhancing the expression of Bcl-XL. Immunity. 3:87-98.

47. Frauwirth, K.A., et al. 2002. The CD28 signaling pathway regulates glucose metabolism. Immunity. 16:769-777.

48. Lenschow, D.J., Walunas, T.L., and Bluestone, J.A. 1996. CD28/B7 system of $\mathrm{T}$ cell costimulation. Annu. Rev. Immunol. 14:233-258.

49. Salomon, B., and Bluestone, J.A. 2001. Complexities of CD28/B7: CTLA-4 costimulatory pathways in autoimmunity and transplantation. Annu. Rev. Immunol. 19:225-252.

50. Viglietta, V., Kent, S.C., Orban, T., and Hafler, D.A. 2002. GAD65-reactive T cells are activated in patients with autoimmune type 1a diabetes. J. Clin. Invest. 109:895-903. doi:10.1172/JCI200214114. 